\title{
"Because if we talk about health issues first, it is easier to talk about human trafficking"; findings from a mixed methods study on health needs and service provision among migrant and trafficked fishermen in the Mekong
}

Nicola S. Pocock ${ }^{1 *}$, Reena Tadee ${ }^{2}$, Kanokwan Tharawan², Wansiri Rongrongmuang ${ }^{3}$, Brett Dickson ${ }^{4}$, Soksreymom Suos ${ }^{5}$, Ligia Kiss ${ }^{6}$ and Cathy Zimmerman ${ }^{6}$

\begin{abstract}
Background: Human trafficking in the fishing industry or "sea slavery" in the Greater Mekong Subregion is reported to involve some of the most extreme forms of exploitation and abuse. A largely unregulated sector, commercial fishing boats operate in international waters far from shore and outside of national jurisdiction, where workers are commonly subjected to life-threatening risks. Yet, research on the health needs of trafficked fishermen is sparse. This paper describes abuses, occupational hazards, physical and mental health and post-trafficking well-being among a systematic consecutive sample of 275 trafficked fishermen using post-trafficking services in Thailand and Cambodia. These findings are complemented by qualitative interview data collected with 20 key informants working with fishermen or on issues related to their welfare in Thailand.

Results: Men and boys trafficked for fishing (aged 12-55) were mainly from Cambodia $(n=217)$ and Myanmar $(n=55)$. Common physical health problems included dizzy spells $(30.2 \%)$, exhaustion $(29.5 \%)$, headaches $(28.4 \%)$ and memory problems (24.0\%). Nearly one-third (29.1\%) reported pain in three or more areas of their body and one-quarter (26.9\%) reported being in "poor" health. Physical health symptoms were strongly associated with: severe violence; injuries; engagement in long-haul fishing; immigration detention or symptoms of mental health disorders. Survivors were exposed to multiple work hazards and were perceived as disposable when disabled by illness or injuries. Employers struggled to apply internationally recommended Personal Protective Equipment (PPE) practices in Thailand. Non-governmental organizations (NGOs) encountered challenges when trying to obtain healthcare for uninsured fishermen. Challenges included fee payment, service provision in native languages and officials siding with employers in disputes over treatment costs and accident compensation. Survivors' post-trafficking concerns included: money problems (75.9\%); guilt and shame (33.5\%); physical health (33.5\%) and mental health (15.3\%).

(Continued on next page)
\end{abstract}

\footnotetext{
* Correspondence: nicola.pocock@unu.edu

${ }^{1}$ United Nations University International Institute of Global Health, UKM

Medical Centre, Jalan Yaacob Latif, Bandar Tun Razak, 56000 Cheras, Kuala

Lumpur, Malaysia

Full list of author information is available at the end of the article
}

(c) The Author(s). 2018 Open Access This article is distributed under the terms of the Creative Commons Attribution 4.0 International License (http://creativecommons.org/licenses/by/4.0/), which permits unrestricted use, distribution, and reproduction in any medium, provided you give appropriate credit to the original author(s) and the source, provide a link to the Creative Commons license, and indicate if changes were made. The Creative Commons Public Domain Dedication waiver (http://creativecommons.org/publicdomain/zero/1.0/) applies to the data made available in this article, unless otherwise stated. 
(Continued from previous page)

Conclusion: Fishermen in this region are exposed to very serious risks to their health and safety, and their illnesses and injuries often go untreated. Men who enter the fishing industry in Thailand, especially migrant workers, require safe working conditions and targeted protections from human trafficking. Survivors of the crime of sea slavery must be provided with the compensation they deserve and the care they need, especially psychological support.

Keywords: Human trafficking, Forced labour, Thailand, Cambodia, Myanmar, Trafficked fishermen, Migrant fishermen, Fishing, Migrant health

\section{Background}

The trafficking of fishermen has emerged as a growing phenomenon in Asia-Pacific [1-5]. Beyond the myriad of occupational risks, including drowning, injuries from operating heavy equipment, fatigue from long working hours, and sleep deprivation from poor weather conditions [6,7], men trafficked for commercial fishing are especially vulnerable to exploitation and abuse because of the isolation in deep off-shore, mobile worksites which evade authorities' interventions. Men trafficked for long-haul fishing may be stranded on vessels for months or years, made possible by transshipment, whereby cargo vessels resupply commercial fishing boats and pick up their catches, obviating the need to dock in port and making escape almost impossible for trafficked men on board [5, 8, 9]. There have been reports of men who, in desperation, jump overboard and drown while fleeing vessels [4]. Even when boats eventually dock at overseas ports, international security regulations often require foreign crew to stay aboard vessels, preventing access to medical care and stopping their escape [10].

Trafficked fishermen report working 18-24 h days with limited to no rest, poor occupational safety and health $(\mathrm{OSH})$ and violence $[1,8,11,12]$. Among a sample of fishermen who were defined as forced labour or trafficked, reports of physical abuse ranged from 10\%-50\%, [11-13] with some of the most extreme violence documented among long-haul fishermen $[8,13,14]$. Men are threatened and beaten with weapons or may be cast overboard by superiors when sick or non-compliant. Men who were regularly physically beaten have contemplated or acted on suicidal thoughts $[8,11,12,14]$.

This study examines health needs and service provision for trafficked and migrant fishermen. In this paper, we use the term "trafficked fishermen" if males have been formally identified as trafficked by authorities. We use the term "migrant fishermen" to describe migrant males who are working in Thailand in the fishing sector, who are not formally identified as trafficked by authorities, some of whom may have experienced some elements of exploitation or trafficking (but not always).

\section{Physical and mental health among labour-trafficked men and associated factors}

Health problems among labour-trafficked men have included headaches, back pain, fatigue, depression, anxiety and PTSD [15]. In addition to violence and restricted freedom during trafficking, mental health disorders among labour-trafficked men in the UK were associated with post-trafficking factors, namely fear of traffickers, absence of a confidante and pre-trafficking sexual violence [16].

Although most literature focuses on the abuses that occur while individuals are in the trafficking situation, previous work has identified multiple health risks that are associated with the post-trafficking period, including during immigration detention and re-trafficking following escape [17]. Trafficked fishermen who manage to escape are frequently detained in immigration detention centres. Many are not formally identified as victims of trafficking and some have been re-trafficked [1, 8, 12, 18]. When detained by authorities and not identified as trafficking victims, men typically must pay fees or bribes to speed up the deportation process or cover their travel expenses home, which is an additional source of stress [1]. Findings from research with asylum seekers and refugees on the health impacts of immigration detention may be relevant for trafficked persons who have experienced trauma. Evidence suggests that among asylum seekers who were torture survivors, immigration detention is linked to mental health disorders, suicidal ideation and self-harm, as well poor physical health from unsanitary conditions and assaults from immigration officers [19].

Somatic symptoms of poor physical health among migrants or trafficked persons may indicate psychological distress, or may result from prolonged exposure to poor conditions, violence and untreated injury [20, 21]. Posttraumatic responses reported by Cambodian migrant workers included: headaches; sleeplessness; dizziness and appetite loss, which were indicated by cultural idioms of distress including "sadness", "thinking too much" and "worry in the heart" [22]; somatic symptoms were also common among traumatized Cambodian refugees [23, 24]. Symptoms of poor physical or mental health can worsen without access to care. 


\section{Healthcare seeking and services for migrant fishermen in Thailand}

Both undocumented migrants and those with work permits may avoid seeking care for fear of arrest or deportation, or they may internalize exclusionary arguments that they are "undeserving" [25, 26], which usually leads to high rates of self-treatment or use of private clinics [27, 28]. Among migrant fishermen in Thailand, higher proportions of Burmese and Khmer fishermen selftreated compared to Thai fishermen [29].

Migrant fishermen in Thailand can enrol in the Health Insurance Card Scheme (HICS), administered the Ministry of Public Health (MOPH). This benefits package includes inpatient and outpatient care, and notably ARV treatment [30]. In 2014, the premium was 2100 THB (66 USD) and 600THB (19 USD) for a pre-employment health screening [31], paid annually by either employer or employee, although the coverage period has now been extended to two years at a cost of 3200 THB (100 USD) and 500 THB (16 USD) respectively [32].

Undocumented migrants can enrol in the HICS, although some hospitals have requested that would-be enrolees show official documents including residence cards [33]. A health screening is conducted alongside registration for temporary work permits (pink card), which restricts migrant workers' movement to their area of employment [26]. Migrants with the pink card are then eligible to apply for temporary passports as part of the Nationality Verification (NV) process, where they then apply for a new work permit with permission to remain legally for two years (renewable up to a maximum of four years) [34]. Blue work permits were issued to migrant workers in land-based sectors, while orange work permits were issued to migrant workers in fishing [35]. At the time of data collection, fishermen were unable to switch their employment to land-based sectors, ostensibly to discourage them from leaving the fishing sector which suffers from labour shortages $[35,36]$.

When this study was conducted in 2014, the HICS was restricted to the hospital where the card was obtained and was not portable between provinces or hospitals, which was problematic for fishermen docking at different provincial ports. Not all migrants enrol, or some enrol but subsequently drop out of the scheme [34]. HICS has improved migrants' access to services and reduced out-of-pocket payments (OPPs), but outpatient utilization rates have remained low. Migrants primarily used only inpatient services, which meant that there were high self-treatment rates and many delayed seeking care [30, 37, 38]. The Social Security Scheme (SSS) provides similar levels of health coverage as the HICS for migrants who entered Thailand via a bilateral Memorandum Of Understanding (MOU) with neighbouring countries, or whom have had passports issued following Nationality Verification. However, under this scheme, both employers and employees must make monthly contributions, and migrants cannot avail of retirement or unemployment benefits despite paying for these. Furthermore, fishermen are effectively ineligible as "informal" sectors including fishing are excluded from the SSS [34, 39]. Provision of health and support services differs for persons formally identified as trafficked by authorities.

\section{Post-trafficking services for trafficked fishermen in Thailand and Cambodia}

Trafficked fishermen formally identified by Thai authorities are sent to one of four shelters for male trafficking survivors, where food, accommodation and vocational training are provided alongside medical care, assistance with legal cases, repatriation and reintegration support [40]. Cambodian trafficked fishermen identified overseas are mainly repatriated via IOM's Assisted Voluntary Return and Reintegration (AVRR) scheme, to temporary accommodation in Phnom Penh where they receive a medical check-up including psychological evaluation, clothing, a cash grant and travel support to return home [41]. Most, if not all, Cambodian men return to deprived rural areas, sometimes with serious psychological conditions, with few or no health services or where they require payments which they often cannot afford. Many suffer with untreated conditions [18]. This study presents the first health data on trafficked fishermen from a large sample and describes how health and welfare providers reach migrant and potentially trafficked fishermen.

\section{Methods}

Analyses were conducted in an exploratory, sequential design. Quantitative data on occupational risks and health needs were analysed first. Subsequent qualitative data analysis explored themes that would benefit from a more in-depth understanding of key topics that were absent from the quantitative data, such as strategies used by providers to reach fishermen and challenges in providing care. While analyses were conducted separately, quantitative and qualitative findings are reported together in Results by theme.

\section{Quantitative data collection}

Quantitative survey data were analysed from structured interviews with 275 male survivors of trafficking for commercial fishing who were in the care of post-trafficking services (as part of a larger study) [42]. The questionnaire was adapted from an instrument used in a prior study with trafficked women using post-trafficking services in Europe [43], to include a wider range of labour sectors. The questionnaire was translated into Khmer, Thai, Vietnamese, Burmese, and Lao, refined through group 
discussions with IOM counter-trafficking teams, further revised through pilot-testing, and reviewed after backtranslation into English [42].

The sample was selected in two stages; first, 15 posttrafficking services were selected based on relationship to IOM country teams and agreements with government agencies. Second, a consecutive sample of service users were asked to participate in interviews carried out by shelter staff within 2 weeks of service admission between December 2011 and May 2013. Trafficked fishermen (including boys) were using either a post-trafficking service in Cambodia or Thailand. Written informed consent was obtained from participants prior to interview; for those aged below 18, the child's care team were also consulted. A strict ethics protocol based on the World Health Organization Ethical Recommendations for Interviewing Trafficked Women was followed [44]. All interviewers had the professional training or experience to identify when an individual should not be interviewed, when to stop or pause an interview, how to respond to distress and when to make necessary referrals. During consent procedures, the interviewer explained the study content and option to refuse or interrupt participation without consequences for services provision [45, 46]. Ethics approval was obtained from the Ministry of Social Development and Human Security in Thailand, the National Ethics Committee for Health Research in Cambodia and the London School of Hygiene and Tropical Medicine (LSHTM).

\section{Data coding and analysis}

Physical health was assessed using an adapted version of the Miller Abuse Physical Symptom and Injury Scale for abuse-specific health problems [47]. A binary variable was created based on a participant endorsing "quite a lot" or "extremely" for each physical health symptom. Binary variables were created for experiencing poor selfassessed health and experiencing 3 or more areas of pain. The 4 most commonly reported physical health symptoms, poor self-assessed health and reporting 3 or more areas of pain were selected as response variables in bivariable analysis.

The occupational health risks (OHR) score was created by combining binary variables on occupational hazard exposures and presence of personal protective equipment for that hazard [46]. Fishermen were categorized as "long-haul" if they were trafficked to Indonesia, Malaysia, Mauritius or South Africa, and "short-haul" if they were trafficked to Thailand, following consultation with study partners. Binary variables were created for ever experiencing a serious injury and ever being detained by authorities. Questions on abuse were derived from the violence and health outcome modules of the WHO multi-country study on intimate partner violence
[48]. Violence was classified as less severe if it involved slaps, pushes and hits, and more severe if it included: being kicked, dragged or beaten up; tied or chained; choked or burned; released a dog to bite or scratch; being threatened with a weapon; cut with a knife, shot or forced to have sex $[49,50]$. The living situation score was the sum of 9 endorsed items; the post-trafficking concern score summed endorsed items from 12 concerns. Mental health was assessed using the Hopkins Symptoms Checklist 25 for depression and anxiety and the Harvard Trauma Questionnaire for post-traumatic stress (PTSD) [51-53]. Binary variables for being symptomatic of anxiety, depression and PTSD were calculated based on cut-off scores of $1.75,1.625$ and 2.0 respectively, as described elsewhere [42].

Unadjusted odds ratios were calculated using logistic regression to explore the relationship between theorized exposures that may impact physical health (see Conceptual Framework A in Additional file 1). We conducted bivariable rather than multivariable analysis due to small sample sizes for the health outcomes and because earlier construction of a Directed Acyclic Graph indicated that our multivariable analysis would be biased due to the direction of the relationships between some theorized predictors [54, 55]. Continuous variables for hours worked/day, OHR score, living situation score and posttrafficking concerns score were rescaled on the interquartile range to aid interpretation in bivariable analyses, where the odds ratio allows comparison between a person with a typical "high" value on the predictor to a person with a typical "low" value [56]. Analysis was conducted in Stata 14.

\section{Qualitative data collection}

A provincial port research site and major fishing hub was chosen as the primary location to interview health and welfare providers and fishery associations, followed by Bangkok, where international organizations were usually based. The port research site is not named to preserve the anonymity of participants.

The topic guide was developed based on themes from a conceptual framework conceived for the study (see Conceptual Framework B in Additional file 1). Semistructured interviews were conducted with key informants between August to October 2014 working either directly with fishermen or on issues related to their welfare (Table 1). Purposive and snowball sampling were used to recruit participants, based on an initial sample frame of service providers compiled from reviewing reports/policy documents. Written informed consent was obtained from each participant. Most interviews were conducted in Thai with a research assistant interpreter, who was trained in interview techniques and topic guide content. Interviews were digitally recorded, transcribed 
Table 1 Participants interviewed for qualitative sample $(n=20)$

\begin{tabular}{ll}
\hline Organization type & Number \\
\hline NGO health and welfare providers (NGO) & 10 \\
Government health and welfare providers (HSP) & 4 \\
Fishery associations (FA) & 3 \\
International organizations (IO) & 3 \\
Total & 20 \\
\hline
\end{tabular}

verbatim to English or Thai and subsequently translated to English. Ethics approval was obtained from the Institute of Population and Social Research, Mahidol University, Thailand and the LSHTM.

\section{Qualitative data coding and analysis}

Qualitative data were analysed using thematic analysis. Transcripts were read and re-read to familiarize with the data and generate initial codes. A priori themes identified from the topic guides and conceptual framework (deductive approach) shaped earlier versions of a coding framework. New codes were also identified from the data (inductive approach). Taken together, emergent codes and a priori codes were collapsed and collated under overarching themes. Themes were continually reviewed for internal consistency and distinguishability from other themes until refined themes were developed, taking care to include negative cases and less prominent themes [57]. Qualitative data were coded and analysed by hand initially, before being coded and sorted in NVivo 11. Finally, memos were developed by theme in OneNote.

\section{Results}

\section{Participant characteristics of trafficked fishermen}

Most long-haul fishermen were from Cambodia (99.0\%) accessing services in Cambodia, while most short-haul fishermen were from Myanmar (71.4\%) accessing services in Thailand (Table 2). Most fishermen (44.7\%) were aged 25 to 34 . Long-haul fishermen were mainly trafficked to Indonesia (65.2\%) and spent much longer time in trafficking situations compared to fishermen on shorthaul boats (median 23 and 5 months respectively). Many long-haul fishermen (43.9\%) reported that they had been detained by authorities compared to $27.3 \%$ of short-haul fishermen. Long-haul fishermen spent a median of one month in immigration or police detention compared to 10 days among short-haul fishermen (Table 2).

\section{Occupational hazards, safety, violence and abuses at sea}

Half (49.5\%) of trafficked long-haul fishermen incurred at least one serious injury compared to $40.0 \%$ of shorthaul fishermen (Table 3). Common accidents and injuries described by NGO participants assisting men included severed limbs, injuries from rope pulleys, winches and sharp fish bones. Other hazards included inhaling poisonous fumes from the fish storage room and men falling off the boat accidentally:

"They work during the night and there are no toilets on the boat. They must walk along the keel and do their business hanging from the boat. If it is a new worker without proper skill there could be a chance that he would fall into the sea and simply disappear." (NGO, 6).

NGOs and industry participants cited crew inexperience leading to accidents and injuries. Swimming under boats to retrieve tangled fishing nets and cutting them from the propeller was another occupational hazard, bringing risk of death among fishermen who did not know how to swim. Children were deemed particularly suited for this task by some employers because captains perceive that they were smaller and more agile to swim under the boat:

"I ask why you (captain) need children in the vessel? They say "sometimes we throw the rope, or for swimming under the fishing vessel, the children are really nice"... (they) swim, pull the rope [free]." (NGO, 13).

Most trafficked short-haul fishermen (84.4\%) reported having no safety or survival equipment compared to 53 . $0 \%$ of long-haul fishermen (Table 3). Just $26.9 \%$ of trafficked fishermen had a life vest. Most short-haul fishermen $(81.8 \%)$ had sun hats compared to $38.4 \%$ of long-haul fishermen, a higher proportion of whom received gloves (76.3\%) compared to short-haul fishermen (31.2\%). An industry participant spoke about the difficulties and questioned the suitability of applying global safety standards and personal protective equipment (PPE) recommendations in the Thai context:

"The ILO had meetings with us about [boat] safety. They told us that, in foreign countries, when we pull the rope, we must put on gloves and shoes. But the foreign fishery and Thai fishery are different. Sometimes wearing gloves can be dangerous as the ropes we use are fluffy and the gloves get stuck. If we don't pull out our hands in time, it can be really dangerous... Sometimes we can't apply some requirements with the way we work." (FA, 21).

He went on to describe other examples of how applying Western safety standards was not suitable:

"Sometimes the ship is slippery and in Europe, the workers put on mechanic jumpsuits. But we can't do this as the weather is really hot and it can be uncomfortable... We only put on working shoes when we go to the cold storage [room] or when we catch live fish and need to protect ourselves from them. Besides that, we don't wear them as they are slippery and uncomfortable." (FA, 21).

This participant alluded to PPE not only being uncomfortable in the climate, but as causing more danger. International organization (IO) participants suggested that $\mathrm{OSH}$ was not prioritized by employers; they did not see it as enough of a problem, and were reluctant to invest in safety measures following already large upfront 
Table 2 Participant characteristics, fishermen using post-trafficking services in Cambodia and Thailand $(n=275)$

\begin{tabular}{|c|c|c|c|c|c|c|}
\hline & \multicolumn{2}{|c|}{ Long-haul fishermen $(n=198)$} & \multicolumn{2}{|c|}{ Short-haul fishermen $(n=77)$} & \multicolumn{2}{|c|}{$\begin{array}{l}\text { Whole sample } \\
(n=275)\end{array}$} \\
\hline & Number & Percent & Number & Percent & Number & Percent \\
\hline \multicolumn{7}{|l|}{ Age } \\
\hline 10 to 14 & - & - & 1 & $1.3 \%$ & 1 & $0.4 \%$ \\
\hline 15 to 17 & 6 & $3.0 \%$ & 6 & $7.8 \%$ & 12 & $4.4 \%$ \\
\hline 18 to 24 & 71 & $35.9 \%$ & 32 & $41.6 \%$ & 103 & $37.5 \%$ \\
\hline 25 to 34 & 96 & $48.5 \%$ & 27 & $35.1 \%$ & 123 & $44.7 \%$ \\
\hline$>=35$ & 25 & $12.6 \%$ & 11 & $14.3 \%$ & 36 & $13.1 \%$ \\
\hline \multicolumn{7}{|l|}{ Education } \\
\hline Primary or less ( $1-5$ grade) & 97 & $49.0 \%$ & 39 & $50.6 \%$ & 136 & $49.5 \%$ \\
\hline Secondary (6-8 grade) & 42 & $21.2 \%$ & 21 & $27.3 \%$ & 63 & $22.9 \%$ \\
\hline Higher (10-11 grade) & 4 & $2.0 \%$ & 6 & $7.8 \%$ & 10 & $3.6 \%$ \\
\hline University degree & - & - & 3 & $3.9 \%$ & 3 & $1.1 \%$ \\
\hline No formal education & 55 & $27.8 \%$ & 8 & $10.4 \%$ & 63 & $22.9 \%$ \\
\hline \multicolumn{7}{|l|}{ Country of destination } \\
\hline China & 2 & $1.0 \%$ & - & - & 2 & $0.7 \%$ \\
\hline Malaysia & 28 & $14.1 \%$ & - & - & 28 & $10.2 \%$ \\
\hline Thailand & 0 & $0.0 \%$ & 77 & $100.0 \%$ & 77 & $28.0 \%$ \\
\hline Indonesia & 129 & $65.2 \%$ & - & - & 129 & $46.9 \%$ \\
\hline Mauritius & 33 & $16.7 \%$ & - & - & 33 & $12.0 \%$ \\
\hline South Africa & 6 & $3.0 \%$ & - & - & 6 & $2.2 \%$ \\
\hline \multicolumn{7}{|l|}{ Home country } \\
\hline Cambodia & 196 & $99.0 \%$ & 21 & $27.3 \%$ & 217 & $78.9 \%$ \\
\hline Myanmar & - & - & 55 & $71.4 \%$ & 55 & $20.0 \%$ \\
\hline Thailand & 2 & $1.0 \%$ & - & - & 2 & $0.7 \%$ \\
\hline Can't remember & - & - & 1 & $1.3 \%$ & 1 & $0.4 \%$ \\
\hline \multicolumn{7}{|l|}{ Time in trafficking (months) } \\
\hline$<1$ & 1 & $0.5 \%$ & 7 & $9.1 \%$ & 8 & $2.9 \%$ \\
\hline 1 to 6 & 25 & $12.6 \%$ & 33 & $42.9 \%$ & 58 & $21.1 \%$ \\
\hline 7 to 12 & 22 & $11.1 \%$ & 14 & $18.2 \%$ & 36 & $13.1 \%$ \\
\hline 13 to 23 & 50 & $25.3 \%$ & 12 & $15.6 \%$ & 62 & $22.5 \%$ \\
\hline$>=24$ & 99 & $50.0 \%$ & 8 & $10.4 \%$ & 107 & $38.9 \%$ \\
\hline Missing data & 1 & $0.5 \%$ & 3 & $3.9 \%$ & 4 & $1.5 \%$ \\
\hline $\begin{array}{l}\text { Median months in trafficking } \\
\text { (median absolute deviation) }\end{array}$ & 197 & $23.0(13.0)$ & 74 & $5.1(3.8)$ & 271 & $16.0(11.5)$ \\
\hline $\begin{array}{l}\text { Speaks language of } \\
\text { destination country }\end{array}$ & 198 & $49.0 \%$ & 77 & $20.8 \%$ & 275 & $41.1 \%$ \\
\hline Previous experience in sector & 15 & $7.6 \%$ & 3 & $3.9 \%$ & 18 & $6.6 \%$ \\
\hline \multicolumn{7}{|l|}{ Country of service access } \\
\hline Cambodia & 198 & $100.0 \%$ & 21 & $27.3 \%$ & 219 & $79.6 \%$ \\
\hline Thailand & - & - & 56 & $72.7 \%$ & 56 & $20.4 \%$ \\
\hline $\begin{array}{l}\text { Ever detained by authorities } \\
\text { in destination country }\end{array}$ & 87 & $43.9 \%$ & 21 & $27.3 \%$ & 108 & $39.3 \%$ \\
\hline
\end{tabular}


Table 2 Participant characteristics, fishermen using post-trafficking services in Cambodia and Thailand $(n=275)$ (Continued)

\begin{tabular}{|c|c|c|c|c|c|c|}
\hline & \multicolumn{2}{|c|}{ Long-haul fishermen $(n=198)$} & \multicolumn{2}{|c|}{ Short-haul fishermen $(n=77)$} & \multicolumn{2}{|c|}{$\begin{array}{l}\text { Whole sample } \\
(n=275)\end{array}$} \\
\hline \multicolumn{7}{|l|}{ Time in detention (months) } \\
\hline$<=1$ & 39 & $44.8 \%$ & 14 & $66.7 \%$ & 53 & $49.1 \%$ \\
\hline 2 to 5 & 35 & $40.2 \%$ & 6 & $28.6 \%$ & 41 & $38.0 \%$ \\
\hline$>=6$ & 13 & $14.9 \%$ & 1 & $4.8 \%$ & 14 & $13.0 \%$ \\
\hline $\begin{array}{l}\text { Median months in detention } \\
\text { (median average deviation) }\end{array}$ & 87 & $1.0(0.9)$ & 21 & $0.3(0.3)$ & 108 & $1.0(0.9)$ \\
\hline
\end{tabular}

costs of the boat, particularly among employers using trafficked labour:

"Safety of the workers is not their priority." (IO, 3).

To improve outcomes, one participant said that boats would have to be redesigned completely, e.g. winches covered, requiring more investment. Other hazards included extreme working hours (median $21 \mathrm{~h} /$ day) among trafficked fishermen; $89.1 \%$ had no or few rest breaks. Half $(52.7 \%)$ of trafficked fishermen had inadequate drinking water; $44.0 \%$ had insufficient food (Table 3). Among key informants, descriptions of food provision varied between inadequate/not fresh to unlimited fresh fish supplied. One government Health Service Provider (HSP) described the case of a fisherman returning from Indonesia with vitamin deficiencies because of a lack of vegetables, as has been observed in several cases of beriberi at Thai ports recently $[58,59]$. Half $(53.8 \%)$ of trafficked fishermen experienced severe violence (Table 3). Being killed and thrown overboard was sometimes threatened by superiors. Among trafficked men who were sold from boat to boat, one participant noted the toll the work would take on men and how quickly they'd fall sick:

"When they sold [a fisherman], first it's 15,000 baht (473 USD), and work 1 year without wages... after that they sold to the second vessel, 8000 baht (252 USD). [They] work maybe 6 to 8 months, until they're sick. No need to treatment. And they throw to the sea." (NGO, 13).

Men were ultimately perceived as disposable once their labour and health had been exhausted. Being forced to take drugs was another abuse, experienced by $7.6 \%$ of long-haul and $1.3 \%$ of short-haul trafficked fishermen (Table 3).

\section{Health as an inroad to assisting trafficked men}

Health and welfare NGOs' mandates involved addressing health (primarily HIV) among migrants, not trafficking. However, their health mandate did grant NGOs access to potentially trafficked fishermen, as health was a less contentious topic for employers. When NGOs provided free medicines and health education, it allowed NGOs to become useful to employers and ultimately gain their trust:

"When we work on AIDs or health issues they are already a soft topic. We sometimes approach [employers] individually and introduce them to our drop in [centre]... The workers can come in and get treated without going to the doctor so [employers] see the benefit of the place... They want their workers to work with them for a long time without sickness or health issue or at least get treated when they do." (NGO, 6).

This participant went on to explain how the NGO's position of putting health before legal concerns about undocumented workers had won employers over:

"Our selling point is that they do not feel that we are harmful to them. Their concern is that they have employed illegal workers, but we assure them we understand that there are many requirements to get the workers registered... At first we were not trusted, but after a time they saw our work and started trusting us." (NGO, 6).

Similarly, other NGO participants discussed using the "healthy employee" frame to encourage employers to invest in migrant fishermen's health. Health provided a less controversial entry point before discussions or awareness raising with employers about trafficking could take place:

"Because if we talk about health first it is easier to talk about human trafficking. That is a serious issue. But when we mix everything in all together I think there is a better chance, I think this is a good strategy." (NGO, 6).

Trafficking is a sensitive subject with employers. Another NGO participant observed that some employers were not receptive to them expanding their remits beyond health to include trafficking, labour conditions or human rights. NGOs might demand that employers improve working or living conditions, or raise awareness among migrant workers about their rights:

"The employer sometimes thinks the NGO is the problem... they don't need us to be close with the fishermen. Because we will teach them everything. They will understand what is their right. That's why, when we need something from [employers], if I need information, it's difficult to go you see. But when I say 'employer, today we have 
Table 3 Occupational hazards, abuses and healthcare during trafficking among fishermen using post-trafficking services in Cambodia and Thailand $(n=275)$

\begin{tabular}{|c|c|c|c|c|c|c|}
\hline & \multicolumn{2}{|c|}{ Long-haul fishermen $(n=198)$} & \multicolumn{2}{|c|}{ Short-haul fishermen $(n=77)$} & \multicolumn{2}{|c|}{ Whole sample $(n=275)$} \\
\hline & Number & Percent & Number & Percent & Number & Percent \\
\hline \multicolumn{7}{|l|}{ Occupational hazards (selected) } \\
\hline Unstable or heavy work platforms & 169 & $85.4 \%$ & 57 & $74.0 \%$ & 226 & $82.2 \%$ \\
\hline $\begin{array}{l}\text { Work along rocky coasts or in } \\
\text { remote offshore }\end{array}$ & 111 & $56.1 \%$ & 68 & $88.3 \%$ & 179 & $65.1 \%$ \\
\hline $\begin{array}{l}\text { Small, unstable or badly maintained } \\
\text { fishing vessel }\end{array}$ & 56 & $28.3 \%$ & 38 & $49.4 \%$ & 94 & $34.2 \%$ \\
\hline $\begin{array}{l}\text { Badly maintained or no fishing } \\
\text { equipment }\end{array}$ & 48 & $24.2 \%$ & 29 & $37.7 \%$ & 77 & $28.0 \%$ \\
\hline $\begin{array}{l}\text { No safety/bad or no survival } \\
\text { equipment }\end{array}$ & 105 & $53.0 \%$ & 65 & $84.4 \%$ & 170 & $61.8 \%$ \\
\hline $\begin{array}{l}\text { Long hours in the sun, cold or } \\
\text { wet without a break }\end{array}$ & 189 & $95.5 \%$ & 77 & $100.0 \%$ & 266 & $96.7 \%$ \\
\hline \multicolumn{7}{|l|}{ Protective gear } \\
\hline Sun hat & 76 & $38.4 \%$ & 63 & $81.8 \%$ & 139 & $50.6 \%$ \\
\hline Gloves & 151 & $76.3 \%$ & 24 & $31.2 \%$ & 175 & $63.6 \%$ \\
\hline Life vest & 59 & $29.8 \%$ & 15 & $19.5 \%$ & 74 & $26.9 \%$ \\
\hline No protective gear given & 28 & $14.1 \%$ & 9 & $11.7 \%$ & 37 & $13.5 \%$ \\
\hline \multicolumn{7}{|l|}{ Hours worked per day } \\
\hline$<=8$ & 13 & $6.6 \%$ & 2 & $2.6 \%$ & 15 & $5.5 \%$ \\
\hline 8 to 10 & 0 & $0.0 \%$ & 5 & $6.5 \%$ & 5 & $1.8 \%$ \\
\hline 11 to 15 & 12 & $6.1 \%$ & 13 & $16.9 \%$ & 25 & $9.1 \%$ \\
\hline 16 to 19 & 9 & $4.5 \%$ & 12 & $15.6 \%$ & 21 & $7.6 \%$ \\
\hline$>=20$ & 103 & $52.0 \%$ & 12 & $15.6 \%$ & 115 & $41.8 \%$ \\
\hline No fixed hours & 61 & $30.8 \%$ & 33 & $42.9 \%$ & 94 & $34.2 \%$ \\
\hline $\begin{array}{l}\text { Median hours worked/day } \\
\text { (median average deviation) }^{\text {a }}\end{array}$ & 137 & $22(2)$ & 44 & $18(3)$ & 181 & $21(3)$ \\
\hline $\begin{array}{l}\text { Occupational health risk score } \\
\text { (median) }^{\mathrm{b}}\end{array}$ & 198 & 50 & 77 & 60 & 275 & 50 \\
\hline Worked every day ${ }^{f}$ & 192 & $97.5 \%$ & 75 & $97.4 \%$ & 267 & $97.5 \%$ \\
\hline No or very few rest breaks & 176 & $88.9 \%$ & 69 & $89.6 \%$ & 245 & $89.1 \%$ \\
\hline No time off for sickness or holiday & 172 & $86.9 \%$ & 67 & $87.0 \%$ & 239 & $86.9 \%$ \\
\hline Experienced at least 1 serious injury ${ }^{9}$ & 98 & $49.5 \%$ & 30 & $40.0 \%$ & 128 & $46.9 \%$ \\
\hline Injuries still cause pain/difficulty & $57 / 98$ & $58.2 \%$ & $9 / 30$ & $30.0 \%$ & $66 / 128$ & $51.6 \%$ \\
\hline Ever needed healthcare or was injured & 129 & $65.2 \%$ & 49 & $63.6 \%$ & 178 & $64.7 \%$ \\
\hline \multicolumn{7}{|l|}{ Who provided medical care ${ }^{d}$} \\
\hline Doctor & 10 & $7.8 \%$ & 2 & $4.1 \%$ & 12 & $6.7 \%$ \\
\hline Nurse & 2 & $1.6 \%$ & - & - & 2 & $1.1 \%$ \\
\hline Owner/manager & 44 & $34.1 \%$ & 13 & $26.5 \%$ & 57 & $32.0 \%$ \\
\hline Co-worker & 8 & $6.2 \%$ & 5 & $10.2 \%$ & 13 & $7.3 \%$ \\
\hline $\begin{array}{l}\text { Received regular health checks } \\
\text { from trafficker/employer }\end{array}$ & 6 & $4.7 \%$ & 2 & $4.1 \%$ & 8 & $4.5 \%$ \\
\hline Other & 2 & $1.6 \%$ & 2 & $4.1 \%$ & 4 & $2.3 \%$ \\
\hline Did not receive healthcare & 61 & $47.3 \%$ & 32 & $65.3 \%$ & 93 & $52.3 \%$ \\
\hline \multirow[t]{2}{*}{ Cheated of wages } & 140 & $70.7 \%$ & 55 & $71.4 \%$ & 195 & $70.9 \%$ \\
\hline & 58 & $\$ 1.33(\$ 1.00)$ & 21 & $\$ 2.52$ & 79 & $\$ 1.44(\$ 1.14)$ \\
\hline
\end{tabular}


Table 3 Occupational hazards, abuses and healthcare during trafficking among fishermen using post-trafficking services in Cambodia and Thailand ( $\mathrm{n}=275)$ (Continued)

\begin{tabular}{|c|c|c|c|c|c|c|}
\hline \multirow{2}{*}{$\begin{array}{l}\text { Median payment in USD/day } \\
\text { (median average deviation) }\end{array}$} & \multicolumn{2}{|c|}{ Long-haul fishermen $(n=198)$} & \multicolumn{2}{|c|}{ Short-haul fishermen $(n=77)$} & \multicolumn{2}{|c|}{ Whole sample $(n=275)$} \\
\hline & & & & $(\$ 1.73)$ & & \\
\hline Restricted freedom ${ }^{e}$ & 162 & $81.8 \%$ & 70 & $90.9 \%$ & 232 & $84.4 \%$ \\
\hline No documents & 151 & $76.3 \%$ & 57 & $75.0 \%$ & 208 & $75.9 \%$ \\
\hline \multicolumn{7}{|l|}{ Violence severity } \\
\hline No violence & 61 & $30.8 \%$ & 18 & $23.4 \%$ & 79 & $28.7 \%$ \\
\hline Experienced less severe violence & 36 & $18.2 \%$ & 12 & $15.6 \%$ & 48 & $17.5 \%$ \\
\hline Experienced more severe violence & 101 & $51.0 \%$ & 47 & $61.0 \%$ & 148 & $53.8 \%$ \\
\hline \multicolumn{7}{|l|}{ Living conditions } \\
\hline $\begin{array}{l}\text { Living and sleeping in } \\
\text { overcrowded rooms }\end{array}$ & 176 & $88.9 \%$ & 67 & $87.0 \%$ & 243 & $88.4 \%$ \\
\hline $\begin{array}{l}\text { Sleeping in dangerous conditions } \\
\text { (close to generator or engine) }\end{array}$ & 80 & $40.4 \%$ & 28 & $36.4 \%$ & 108 & $39.3 \%$ \\
\hline Nowhere to sleep/sleeping on the floor & 141 & $71.2 \%$ & 71 & $92.2 \%$ & 212 & $77.1 \%$ \\
\hline Poor basic hygiene & 127 & $64.1 \%$ & 52 & $67.5 \%$ & 179 & $65.1 \%$ \\
\hline Inadequate water for drinking & 101 & $51.0 \%$ & 44 & $57.1 \%$ & 145 & $52.7 \%$ \\
\hline Insufficient food & 94 & $47.5 \%$ & 27 & $35.1 \%$ & 121 & $44.0 \%$ \\
\hline No clean clothing items & 155 & $78.3 \%$ & 64 & $83.1 \%$ & 219 & $79.6 \%$ \\
\hline Overexposure to sunlight or rain & 191 & $96.5 \%$ & 76 & $98.7 \%$ & 267 & $97.1 \%$ \\
\hline Other hazards & 30 & $15.2 \%$ & 21 & $27.3 \%$ & 51 & $18.6 \%$ \\
\hline Living situation score $\left(\right.$ mean, SD) ${ }^{c}$ & 198 & $5.5(1.8)$ & 77 & $5.8(1.9)$ & 275 & $5.6(1.8)$ \\
\hline \multicolumn{7}{|l|}{ Alcohol } \\
\hline Never drank alcohol & 86 & $43.4 \%$ & 44 & $57.1 \%$ & 130 & $47.3 \%$ \\
\hline Drank afew times per year & 82 & $41.1 \%$ & 13 & $16.9 \%$ & 95 & $34.6 \%$ \\
\hline Drank afew times per month & 23 & $11.6 \%$ & 19 & $24.7 \%$ & 42 & $15.3 \%$ \\
\hline Drank afew times per week & 4 & $2.0 \%$ & 1 & $1.3 \%$ & 5 & $1.8 \%$ \\
\hline Drank everyday & 3 & $1.5 \%$ & - & - & 3 & $1.1 \%$ \\
\hline $\begin{array}{l}\text { Forced to take drugs by } \\
\text { employer or trafficker }\end{array}$ & 15 & $7.6 \%$ & 1 & $1.3 \%$ & 16 & $5.8 \%$ \\
\hline
\end{tabular}

${ }^{a}$ Among those who specified hours worked

${ }^{\mathrm{b}}$ Score $\min =0, \max =100$

${ }^{\mathrm{C} S}$ core $\min =0, \max =9$

${ }^{d}$ Among those ever injured or specifying that they needed care during trafficking

eEither "Never" being free or being locked in a room

${ }^{f} 1$ missing

${ }^{9} 2$ missing

announcement from $\mathrm{MOH}$, maybe you get vaccine'...If we go and give, the employer allows." (NGO, 13).

"We just step in about health issues first... [employers] really like that. Not the human rights issue..." (NGO, 7).

NGOs had a better chance of safeguarding access to fishermen via free health services or education, which gave employers benefits in the form of a healthier workforce. To preserve access, NGOs could not be seen to be assisting trafficking cases directly. Instead they referred potential cases to a government unit or another NGO (not from the local area) to conduct the rescue:

"If I go to that area and help a trafficking case, maybe the trafficker will say 'next time don't allow this van go to this area'. And now I [provide] HIV training, health education, medicines, then we can get closer with the fishermen. Then we can talk with them "what happened?" If its trafficking or something they can report to us." (NGO, 13).

This strategy safeguarded NGOs' access to the area for health promotion and continued monitoring of potential trafficking cases.

\section{Healthcare and contact with health providers}

Most (86.9\%) trafficked fishermen could not take time off for sickness or holidays, but two thirds (64.7\%) reported ever needing healthcare or being injured (Table 3). Among 
them, 52.3\% said they did not receive care. Most longhaul fishermen (58.2\%) were still in pain from their injuries at the time of interview. Among those who received care, one-third $(32.0 \%)$ said they received some form of care from their manager, $7.3 \%$ said they were treated by co-workers and just $6.7 \%$ saw a doctor. Following accidents and injuries, lack of first aid knowledge at sea was cited as a problem among health and welfare providers, leading to makeshift self-treatment by fishermen:

"We only saw workers who have been in accidents and are getting complications. For example if a worker got his hand into the boat winch and bled, he would put tobacco paste on it, [causing] swelling or inflammation. Or... if a worker broke his arm he would just put oil on it instead of using a slab to hold it in place. The bone would join themselves back together in 15 days [resulting] in a crooked arm. They do not know how to do it properly... a lot of people get stung by jelly fish and when they don't do first aid complications will follow. That takes us longer to treat them. That is an important issue." (HSP, 27).

Self-treatment without proper knowledge could result in long-term harm e.g. wrongly fused bones.

\section{Availability}

Drop in centres, port outreach and mobile health units ensured availability of primary health services for migrant fishermen. Drop in centres were inviting, including free snacks, books, television; men could access health information, STI testing and Voluntary Counselling and Testing (VCT) for HIV/AIDs. Staff availability was a key theme:

"(This centre) opens at 8 and closes at 5. But we usually we accept people the whole day because the staffs are always here. If you want to drop by then just knock on the door anytime." (NGO, 15).

One health provider described a pilot Floating Hospital initiative, whereby short-haul fishermen were trained in basic first aid and given medicines to dispense at sea. Participating boats with at least one trained fisherman were given a flag so that other boats could recognise and approach it when men were injured or sick. When boats docked, serious cases were referred to the hospital via mobile health units near ports:

"We have a mobile health unit to do check-ups for crew members. [We diagnose] chronic diseases that are not contagious, diabetes, and high blood pressure. There is also waist measurement to gauge the possibility of being overweight." (HSP, 27).

Beyond treating injuries, this health provider was concerned about chronic diseases and related risk factors among fishermen. One industry participant described the MOPH doing health checks for infectious diseases among crew on boats returning from international waters:

"... Sometimes they come with diseases... [MOPH] has a space, like the airport... Sometimes the (crew) just walk through, nobody there. [But] if there's some news about [infectious diseases], now Ebola, if the plane comes from West Africa, then [MOPH] has to come." (FA, 8).

During a global infectious disease outbreak, where state concerns about disease transmission from mobile groups like fishermen was heightened, checks were more likely to be carried out according to this participant.

\section{Health worker attitudes}

Staff attitudes and fear of arrest partly governed the decision around which health provider to bring migrant workers. Private clinics where fees could be paid upfront asked fewer questions and were sometimes considered a safer and easier option. This NGO participant suggested that staff at government hospitals were prejudiced against migrant workers who requested fee waivers:

"Sometimes we don't go to the hospital... We, they [migrant] are scared. We bring them to the sub district hospital... a small treatment centre... If we pay cash they don't ask too much. If we need assistance from government... Sometimes the hospital (staff) think that the migrant is spending our Thai budget... They don't like it. Their acting is not human, [like migrants] are not same as their level. They study nurse, the study doctor, but they don't have heart." (NGO, 13).

This participant expressed disappointment in health workers who seemed to lack professional ethics in treating migrant workers well, due to inability to pay or perhaps racism. Transporting undocumented migrants in Thailand is illegal, thus getting fishermen to larger, public HSPs entailed personal risk for this participant:

"Sometimes we go to a nearby clinic, pay money and finish... Sometimes we don't need to bring them far from their home... maybe I will be arrested... Because they are illegal." (NGO, 13).

Other NGO participants discussed similar fears of arrest and how the law prompted them to be very careful with their work. One participant's colleague faced criminal charges for transporting an undocumented migrant in their car. Other participants suggested that health workers were welcoming of migrants in healthcare settings, linked to higher volumes of migrants entering Thailand and the ASEAN Economic Community's (AEC) policy encouraging freer labour movement:

"But I feel like the new doctors that recently graduated are friendly to Burmese because they see more of them and AEC is opening soon. They tell me what they expect from these workers and ask if there is anything they could do to help develop them." (NGO, 15). 
"[Our] hospital is like their ally. [Migrants] can come with or without the money. They are not afraid of this hospital." (HSP, 27).

In high migration areas where these participants were based, younger doctors and HSPs may be more familiar with and kinder towards migrants seeking care.

\section{Paying for treatment}

Among trafficked fishermen, 70.9\% were cheated of wages and among the few men who received wages these were extremely low (median US\$1.44/day) (Table 3), implying that it would be near impossible to pay out-ofpocket for healthcare. Existing long term relationships with HSPs were important when it came to negotiating free treatment, or flexibly paying costs over time, for uninsured migrant workers. When employers refused to pay for treatment, NGOs often had to step in and negotiate with hospitals on fishermen's behalf:

"We have to check the cost, for example 5000 baht (158 USD). [Fisherman] do not have [that money]. So, that hospital say we only need to pay for the treatment or the medicine... they reduce the cost. So we agree, OK we'll pay 2000 baht (63 USD). So the hospital say OK... But sometimes it's very difficult also." (NGO, 17).

HSPs had discretion to waive fees entirely, or request payment for specific items only. When fees could not be waived entirely, one NGO participant described migrant savings clubs making up the shortfall where fishermen were members. For men in post-trafficking care, hospital invoices would be sent to the Anti-Human Trafficking Fund for payment. Both NGO and government health and welfare providers were concerned about budget constraints when paying treatment costs for uninsured migrants. One HSP noted high awareness among migrants and NGOs about the HSP's duty to provide free care when needed:

"[Migrants] knew that the government hospitals must give free treatments. We are still doing it now, giving free treatments to illegal foreign workers. In the past 5 years that has cost us 65 million baht ( 2 million USD). We did not get even a single baht back. 65 million baht, we are in trouble... When we are working with NGO we always request them to help find funding for the government hospital but they always refuse us saying it would be illegal to do so. It is very difficult because it is the government hospital's responsibility to provide treatment to everyone in need." (HSP, 27).

This participant highlighted the difficulty of balancing budgets while fulfilling both a legal and moral duty to provide care. Enrolling in the Health Insurance Card Scheme (HICS) was one suggested solution, but fishermen "outside the border" were less likely to enrol than migrants working in other sectors. HICS could only be used for healthcare in Thailand, so long-haul fishermen on boats departing for Indonesia or elsewhere would not be able to use HICS for treatment costs incurred overseas. Other barriers to uptake of HICS included fishermen only being concerned with their health when they had an accident, by which time they would have to pay out-of-pocket. The HSP participant noted that discontinuity of care was common among fishermen because of limited time onshore to have check-ups and get medicines. Some inpatients discharged themselves early to avoid paying for treatment. One NGO participant explained how fishermen were also unlikely to avail of health benefits under the Social Security Scheme (SSS) as they did not enter Thailand via the MOU. Fishermen were entirely dependent on employers' goodwill to pay out-of-pocket when they were not registered:

"On one boat, there are approximately 40 men, maybe only 2 have documents - pink card [work permit] or passport. Employers don't normally register them... When they get sick, it depends on how much the employers will take care of them." (NGO, 25).

NGOs were often contacted by fishermen to help negotiate settlements with employers. One participant discussed numerous challenges in obtaining accident compensation for migrant workers:

"Mostly it's the social security officers, they try to say that the employers have paid for the treatment, they paid like hundreds of thousand baht... Sometimes they think we are the one who told the employee to be tough. But our duty is to explain to the employees what their losses are, how much they should be compensated. Employees are threatened by employers too. Sometimes we have to help the employees; when they had an accident at work, they cannot work, we have to take care of their rent and food until the case is closed. There are many challenges. Everyone is threatened." (NGO, 25).

Social security and other government officers also sided with employers during disputes according to other participants, indicating that migrant testimony is not taken seriously by authorities compared to employers' claims. Employers may threaten migrant employees and NGOs not to pursue compensation claims to avoid payouts.

\section{Language barriers, interpreters and treatment}

Among trafficked fishermen, just $41.1 \%$ could speak the language of the destination country (Table 2). Key informants described language barriers as deterring migrant workers from seeking care, or from understanding the benefits of migrant health insurance; one suggested that some health workers' poor attitudes towards migrants were amplified by frustrations around language:

"Sometimes, the nurse, or official in the hospital sometimes they don't welcome [migrants]... in my place we don't have an interpreter in Myanmar or Cambodia 
language, and then when the nurse shouting them, they don't want to go. They have problems." (NGO, 13).

Lack of interpreters in health facilities and the possibility of being reprimanded for language inability discouraged migrants from seeking care. Migrant health volunteer (MHV) interpreters were key in facilitating access to care. An NGO participant who had played a major role initiating a provincial MHV program with the $\mathrm{MOPH}$ described high demand for interpreter services. MHVs were not paid, but took pride in their work; they were trained by the NGO and the local public hospital; doctors had translated medical terms to Burmese for the MHV handbook. Being a MHV was a privilege that extended to affording protection from the police, who might otherwise arrest migrant workers:

"Each volunteer will get a Migrant Worker Volunteer shirt... They would let the governor sign their shirts so that the police know they are working with the Health Department and will not arrest them." (NGO, 15).

The MHV program had extensive support from the provincial health office and governor, indicating that local authorities valued the health of migrants. This support enabled MHVs to operate without having to worry about being arrested. Another participant whose NGO organized their own migrant health interpreters described how employers appreciated this service:

"We have officers and volunteers that can speak Cambodian. We can understand them. When workers are sick, employers send them to the drop in [centre] to let them go to the hospital with volunteers so that they can translate for them. Now the employers saw what we do so they have given us a car to deliver patients. In some cases the workers are sick and they want to go home, we send them all the way to the border with expenses covered by employers." (NGO, 6).

Employers saw value in interpreter services, engendering further cooperation and a positive relationship with the NGO. Over half of trafficked fishermen (61.7\%) were symptomatic of any mental health disorder (Table 4). Key informants also discussed challenges finding interpreters or counsellors speaking native languages in posttrafficking care. One shelter described calling interpreters to translate by phone, or sometimes requesting a resident trafficked person with language skills to interpret. The same shelter usually observed mental health problems among Thai and not migrant residents, for reasons that are unclear but may be related to lack of interpreters to facilitate diagnosis or treatment. One IO provided an additional psychologist and interpreter to support the shelter psychologist with group and individual counselling. Another participant noted that culturally, migrant men dealt with trauma by "getting on with things", which may be related to treatment in other languages being unavailable:
"They're kept in the shelters simply for rehabilitation purposes, which generally fishermen, there's really not much involved in rehabilitation. For migrants... of course they suffer the trauma, but it's a very different way of dealing with trauma in this culture, you just get on with things... and the centres are not equipped to provide counselling to people in different languages... They have very basic translators... this is not the kind of advanced stuff, if you're going to give psychological counselling, you at least need to have decent translators, otherwise how could you do it?" (IO, 2).

For this participant, having professional interpreters, perhaps with medical or specialist knowledge, as opposed to informal interpreters, was considered important to provide appropriate treatment.

\section{Physical and mental health, post-trafficking concerns}

Key informants described seasickness, headaches, muscle pain, fevers and colds as health problems among men at sea, although one HSP noted that it was difficult to know about health problems faced by longhaul fishermen because they did not self-identify as such when seeking care. Among trafficked fishermen, the most commonly reported physical health symptoms were: dizzy spells (30.2\%); feeling completely exhausted (29.5\%); headaches $(28.4 \%)$; memory problems $(24.0 \%)$ (Table 4). If fishermen had escaped trafficking, those who had experienced abuse may experience memory problems:

"Sometimes these people they tend to forget their actual age already because of the continued abuse and exploitation." (NGO, 7).

Memory problems can complicate repatriation when men forget key information, e.g. names and home addresses. A quarter (26.9\%) of trafficked fishermen reported poor self-assessed health and $29.1 \%$ reported pain in three or more areas (Table 4). The majority (70. $0 \%$ ) wanted to see a doctor or nurse for their symptoms. Trafficked fishermen had high symptom levels for depression (54.4\%), PTSD (39.4\%) and anxiety (44. 9\%); long-haul fishermen had worse mental health than short-haul fishermen; 69.5\% of long-haul fishermen were symptomatic of any mental health disorder and 9 . $1 \%$ had suicidal thoughts, compared to $41.6 \%$ and $2.6 \%$ of short-haul fishermen respectively (Table 4 ). Moneyrelated concerns $(75.9 \%)$ and health-related problems in the family $(46.7 \%)$ were the main post-trafficking concerns among trafficked fishermen (Table 4). Higher proportions of long-haul fishermen were concerned for their physical health (37.1\%) and mental health (18.3\%), compared to $24.7 \%$ and $7.8 \%$ respectively among shorthaul fishermen. A third (33.6\%) were concerned about guilt or shame. 
Table 4 Physical and mental health symptoms and concerns post-trafficking among fishermen using post-trafficking services in Cambodia and Thailand $(n=275)$

\begin{tabular}{|c|c|c|c|c|c|c|}
\hline & \multicolumn{2}{|c|}{ Long-haul fishermen $(n=198)$} & \multicolumn{2}{|c|}{ Short-haul fishermen $(n=77)$} & \multicolumn{2}{|c|}{ Whole sample $(n=275)$} \\
\hline & Number & Percent & Number & Percent & Number & Percent \\
\hline \multicolumn{7}{|l|}{ Symptom $^{a}$} \\
\hline Dizzy spells & 69 & $34.9 \%$ & 14 & $18.2 \%$ & 83 & $30.2 \%$ \\
\hline Headaches & 67 & $33.8 \%$ & 11 & $14.3 \%$ & 78 & $28.4 \%$ \\
\hline Dental problems & 32 & $16.2 \%$ & 10 & $13.0 \%$ & 42 & $15.3 \%$ \\
\hline Nausea/indigestion & 46 & $23.2 \%$ & 10 & $13.0 \%$ & 56 & $20.4 \%$ \\
\hline Diarrhea/gastrointestinal & 24 & $12.1 \%$ & 8 & $10.4 \%$ & 32 & $11.6 \%$ \\
\hline Back pain & 40 & $20.2 \%$ & 17 & $22.1 \%$ & 57 & $20.7 \%$ \\
\hline Skin problems & 37 & $18.7 \%$ & 14 & $18.2 \%$ & 51 & $18.6 \%$ \\
\hline Feeling completely exhausted & 63 & $31.8 \%$ & 18 & $23.7 \%$ & 81 & $29.5 \%$ \\
\hline Fainting & 6 & $3.0 \%$ & 2 & $2.6 \%$ & 8 & $2.9 \%$ \\
\hline Significant weight loss & 56 & $28.3 \%$ & 7 & $9.1 \%$ & 63 & $22.9 \%$ \\
\hline Memory problems & 58 & $29.3 \%$ & 8 & $10.4 \%$ & 66 & $24.0 \%$ \\
\hline Persistent coughing & 33 & $16.7 \%$ & 5 & $6.5 \%$ & 38 & $13.8 \%$ \\
\hline Reporting $>=3$ areas of pain & 62 & $31.3 \%$ & 18 & $23.4 \%$ & 80 & $29.1 \%$ \\
\hline \multicolumn{7}{|l|}{ Self-assessed health (past month) } \\
\hline Poor & 63 & $31.8 \%$ & 11 & $14.3 \%$ & 74 & $26.9 \%$ \\
\hline Fair & 100 & $50.5 \%$ & 27 & $35.1 \%$ & 127 & $46.2 \%$ \\
\hline Good & 34 & $17.2 \%$ & 32 & $41.6 \%$ & 66 & $24.0 \%$ \\
\hline Very good & 1 & $0.5 \%$ & 7 & $9.1 \%$ & 8 & $2.9 \%$ \\
\hline $\begin{array}{l}\text { Want to see doctor or nurse for } \\
\text { these symptoms\# }\end{array}$ & 135/177 & $76.3 \%$ & $35 / 66$ & $53.0 \%$ & $170 / 243$ & $70.0 \%$ \\
\hline \multicolumn{7}{|l|}{ Post-trafficking mental health ${ }^{b}$} \\
\hline Symptomatic of depression & 122 & $61.9 \%$ & 27 & $35.1 \%$ & 149 & $54.4 \%$ \\
\hline Symptomatic of PTSD & 94 & $47.7 \%$ & 14 & $18.2 \%$ & 108 & $39.4 \%$ \\
\hline Symptomatic of anxiety & 106 & $53.8 \%$ & 17 & $22.1 \%$ & 123 & $44.9 \%$ \\
\hline $\begin{array}{l}\text { Symptomatic of any Mental } \\
\text { Health Disorder (MHD) }\end{array}$ & 197 & $69.5 \%$ & 77 & $41.6 \%$ & 169 & $61.7 \%$ \\
\hline Self-harm & 11 & $5.6 \%$ & 3 & $3.9 \%$ & 14 & $5.1 \%$ \\
\hline Suicide attempts & 11 & $5.6 \%$ & 1 & $1.3 \%$ & 12 & $4.4 \%$ \\
\hline Thoughts of ending your life & 18 & $9.1 \%$ & 2 & $2.6 \%$ & 20 & $7.3 \%$ \\
\hline \multicolumn{7}{|l|}{ Post-trafficking concerns ${ }^{b}$} \\
\hline Own physical health & 73 & $37.1 \%$ & 19 & $24.7 \%$ & 92 & $33.6 \%$ \\
\hline Own mental health & 36 & $18.3 \%$ & 6 & $7.8 \%$ & 42 & $15.3 \%$ \\
\hline Earning money/having job/paying debt & 110 & $55.8 \%$ & 24 & $31.2 \%$ & 134 & $48.9 \%$ \\
\hline Nowhere to stay short term & 17 & $8.6 \%$ & 4 & $5.2 \%$ & 21 & $7.7 \%$ \\
\hline Nowhere to stay long term & 45 & $22.8 \%$ & 12 & $15.6 \%$ & 57 & $20.8 \%$ \\
\hline Money-related problems in family & 130 & $66.0 \%$ & 40 & $52.0 \%$ & 170 & $62.0 \%$ \\
\hline Health-related problems in family & 90 & $45.7 \%$ & 38 & $49.4 \%$ & 128 & $46.7 \%$ \\
\hline Afraid of trafficker or associates & 11 & $5.6 \%$ & 10 & $13.0 \%$ & 21 & $7.7 \%$ \\
\hline Guilt or shame & 73 & $37.1 \%$ & 19 & $24.7 \%$ & 92 & $33.6 \%$ \\
\hline Documents & 15 & $7.6 \%$ & 21 & $27.3 \%$ & 36 & $13.1 \%$ \\
\hline Spiritual/religious concerns/ghosts & 7 & $3.6 \%$ & 7 & $9.1 \%$ & 14 & $5.1 \%$ \\
\hline Other & 24 & $12.2 \%$ & 23 & $29.9 \%$ & 47 & $17.2 \%$ \\
\hline
\end{tabular}


Table 4 Physical and mental health symptoms and concerns post-trafficking among fishermen using post-trafficking services in Cambodia and Thailand $(n=275)$ (Continued)

\begin{tabular}{|c|c|c|c|c|c|c|}
\hline \multirow[b]{2}{*}{ No concerns } & \multicolumn{2}{|c|}{ Long-haul fishermen $(n=198)$} & \multicolumn{2}{|c|}{ Short-haul fishermen $(n=77)$} & \multicolumn{2}{|c|}{ Whole sample $(n=275)$} \\
\hline & 5 & $2.5 \%$ & 8 & $3.5 \%$ & 13 & $4.7 \%$ \\
\hline $\begin{array}{l}\text { Money concerns } \\
\text { (aggregate personal or family) }\end{array}$ & 161 & $81.7 \%$ & 47 & $61.0 \%$ & 208 & $75.9 \%$ \\
\hline Post-trafficking concern score (mean) ${ }^{c}$ & 198 & 3.2 & 77 & 2.9 & 275 & 3.1 \\
\hline
\end{tabular}

"Proportion endorsing "quite a lot" or "extremely"

${ }^{b}$ One missing for depression, anxiety, each post-trafficking concern, self-harm, suicide attempts among long-haul fishermen/whole sample ${ }^{\mathrm{S} S} \mathrm{core} \min =0, \max =12$

\section{Factors associated with poor physical health}

Among trafficked fishermen, being injured was strongly associated with all physical health symptoms, particularly dizzy spells (UOR 3.39, CI:1.97-5.86) and headaches (UOR 3.13, CI: 1.80-5.43) (Table 5). More severe violence was associated with most physical health symptoms, e.g. dizzy spells (UOR 3.27, CI: 1.65-6.45), poor self-assessed health (UOR 3.41, CI: 1.61-7.20). Being symptomatic of mental health disorders was strongly associated with all physical health symptoms, e.g. pain in three or more areas (UOR 9.00, CI: 4.11-19.68); wide confidence intervals indicate that findings should be interpreted cautiously. Being a long-haul fisherman was associated with most symptoms, e.g. memory problems (UOR 3.57, CI:1.61-7.90). Experiencing more poor living conditions was associated with poor self-assessed health (UOR 2.42, CI: 1.49-3.93); being detained was associated with memory problems (UOR 4.14, CI: 2.30-7.43); being trafficked for more than six months was associated with pain in three or more areas (UOR 3.81, CI: 1.72-8.41). Financial concerns were associated with poor self-assessed health (UOR 2.17, CI:1.06-4.42) and headaches (UOR 2. 04, CI: 1.02-4.08). Feeling guilt or shame was associated with poor self-assessed health (UOR 2.08, CI: 1.20-3.60).

\section{Discussion}

Trafficked long-haul fishermen experienced a higher burden of serious injuries and poor health than short-haul fishermen in our sample. Qualitative findings raise questions about adapting Personal Protective Equipment (PPE); how might clothing and PPE be adapted to the weather and Thai context so that fishermen are protected? Besides intense physical exertion, unsanitary, cramped living conditions and poor nutrition exacerbate poor health. Following deaths from beriberi (caused by vitamin B1 deficiencies) linked to such conditions among fishermen [58, 60], $\mathrm{MOPH}$ issued guidance on beriberi prevention in the sector is welcomed but it remains to be seen how this information will reach captains and fishermen [61]. We know little about what works to reduce occupational injury and uptake of PPE in low and middle income countries [62]; formative research with migrant fishermen should examine feasibility of different culturally appropriate interventions.
Transshipment in long-haul fishing has undoubtedly contributed to vulnerability and has exacerbated health problems of migrant and trafficked fishermen at sea for extremely long periods. Self-treatment or receiving care from superiors was common in our sample; qualitative findings indicated that such treatment took place without accurate health or first aid knowledge. The Floating Hospital model of having first aid trained fishermen with medicines on boats holds promise, particularly for longhaul fishermen whom cannot reach shore on time following injuries. Encouragingly since September 2016, the Thai government has banned transshipment at-sea permanently, and observers on board are now required by law on all Thai overseas commercial fishing vessels. These observers could be trained in first aid and treatment applications for commonly experienced conditions among long-haul fishermen. July 2016 saw the dispatch of the first fisheries observers to the long-haul fishing fleet, but it is unknown whether they had any health background or training [59].

Making health services migrant friendly is important. Our findings corroborate those in other settings; HSPs are torn between budget constraints and duty to provide care, employing strategies like fee waivers and partnering with NGOs to cover treatment costs [63]. Men tend to delay seeking healthcare when ill [64], indicating that preventive interventions, via port outreach and mobile health units, must continue. Improved registration of migrant fishermen is needed; reforms allowing HICS benefits to be portable would help fishermen to access services wherever they dock in Thailand. Employers of long-haul fishermen should be required to purchase international policies when men apply for work permits; the Ministry of Labour could consider including health insurance on the labour inspection checklist. Our findings show that interpreters encouraged care-seeking and built goodwill with employers. The Migrant Health Volunteer model holds promise, although it has only been implemented in two coastal provinces [65]. In another large-scale NGO program, Migrant Field Officers provide similar support alongside negotiating disputes with police, employers and health workers [66]. In Thailand's civil service, foreigners are limited to low skilled work 


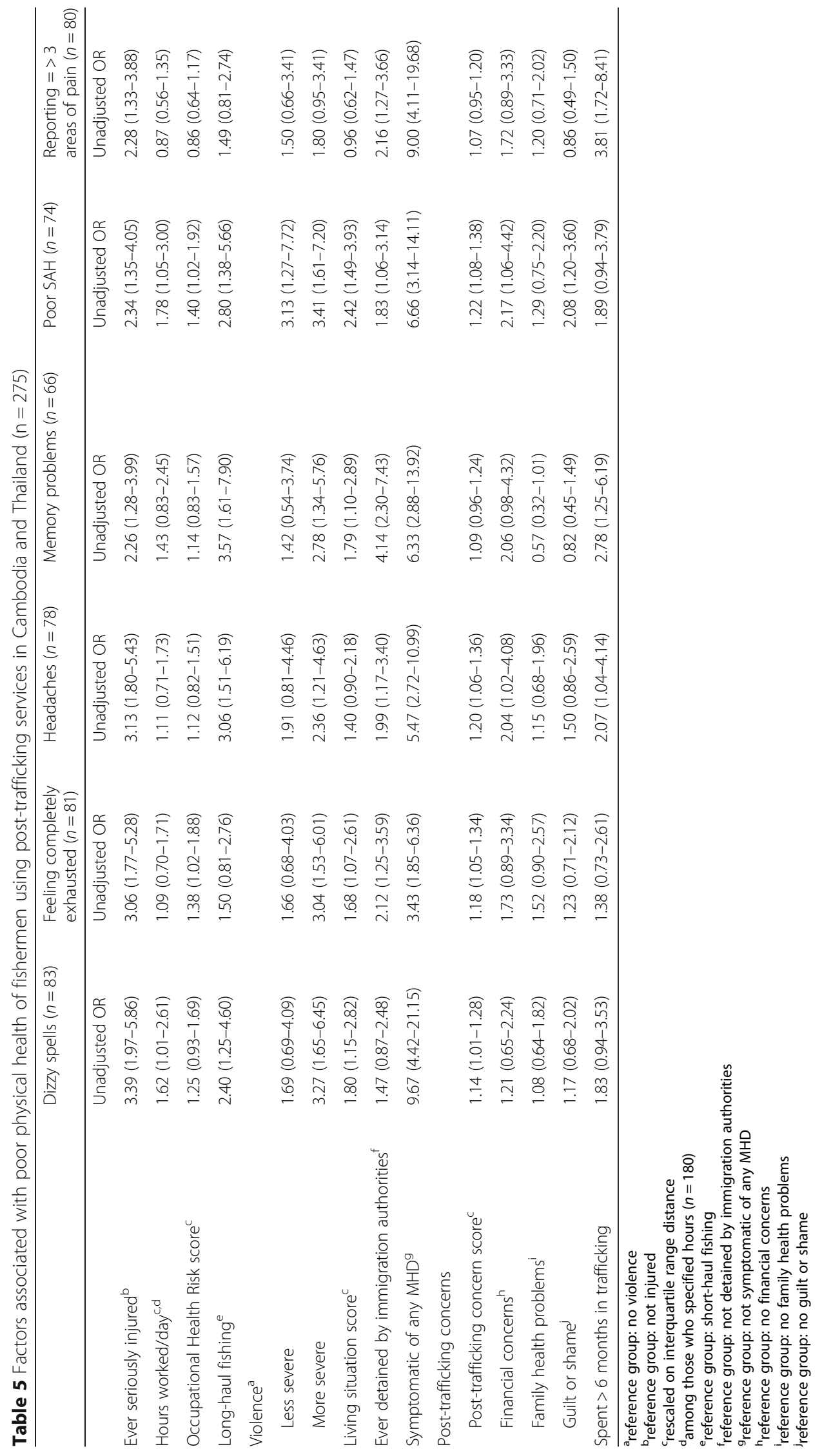


and cannot officially be hired as professional interpreters. The government recently announced that migrants could work as "language assistants" but it is too early to tell whether and how this policy affects health or support services for migrant or trafficked fishermen [67]. To date, some migrant interpreters have been employed as cleaners by hospitals who find budget lines to do this. The volunteer MHV scheme itself is hampered by sustainability and budgetary concerns [68]. As per systematic review findings on care provision for migrants, informal interpreters (e.g. friends, family) are considered appropriate by providers when clinical situations are uncomplicated (e.g. coughs, fever) [63], but for mental health or serious conditions trained interpreters are important. Despite interpreters' valuable role in healthcare settings [69], there appears to be little policy discussion about interpreter services in Thailand. Formative pilot research and economic evaluation of different modalities of interpreting (e.g. including use of information technologies, NGO partnerships) using available conceptual tools [70] may be beneficial to ascertain what could feasibly be implemented in the Thai context.

Stark differences in mental health between long and short-haul fishermen suggest pernicious psychological effects of being trafficked for extended periods at sea. Symptoms of depression and PTSD were more common in our sample compared to adult refugees and conflict afflicted populations where prevalence was measured with similar instruments [71]. With few mental health professionals there are limited referral options; in Cambodia, only severe psychiatric cases among trafficked men were referred to health providers [18]. Men may be "unwilling victims" of trafficking and stigma associated with mental health support may influence care seeking [72, 73]; many trafficked Ukrainian seafarers and fishermen did not seek psychological support because they perceived using services as signs of weakness and debilitation [74]. As our findings show, despite the high burden of mental health symptoms, just $15.3 \%$ were concerned for their mental health. Mental health is essential in packages of care for trafficking survivors; research is urgently needed to identify culturally appropriate mental health interventions with men that can be implemented by non-professionals in low-resource settings [42].

Fishermen's financial concerns, as well as guilt or shame, were associated with poor physical health, which itself may be a somatic symptom of serious psychological distress indicated in our findings. Rescued men often return to deprived origin communities where prospects for work and income are limited, prompting many to re-migrate [18]. Feelings of guilt and shame from failure to fulfil breadwinner expectations are common [75]; Cambodian trafficked fishermen report ridicule from family members for not bringing money home, or some return home to find wives remarried, which may complicate men's access to social support [18, 76] Fishermen returning with many tattoos have been stigmatized as gangsters or troublemakers, with some reporting discrimination in the job market as a result [76]. In Thailand, promising reforms in 2016 allow trafficked persons to work on one year visas with a quicker application process, with the Anti-Human Trafficking fund covering health insurance and medical examinations needed to apply for work permits [77].

Our study has some limitations. We did not ask fishermen about the duration of their trips at sea. Mental health symptoms may be endorsed differently by nationality. Instruments to measure mental health symptoms were not diagnostic but have been used with traumatized refugees in the same region and among posttrafficking service users in Europe [43, 78, 79]. PTSD symptoms should be interpreted with caution as they may be capturing Acute Stress Disorder [42, 80]. We were only able to conduct bivariable analyses due to small sample sizes for the health outcomes and causal diagrams indicated that multivariable analyses would be biased due to the direction of theorized relationships [81]. While we cannot generalize from qualitative findings, they offer important insights about how service providers reach and assist migrant and potentially trafficked fishermen.

\section{Conclusion}

Improving migrant and potentially trafficked fishermen's health requires greater investment in $\mathrm{OSH}$ interventions and migrant friendly health services. Trafficked fishermen face immense ill-health, particularly trafficked long-haul fishermen, yet resources to restore their wellbeing are not commensurate: most services in the Mekong focus on the needs of women and girls $[82,83]$. Now is the time to invest in service provision and research on culturally appropriate care and interventions for migrant and potentially trafficked fishermen.

\section{Additional file}

Additional file 1: Conceptual Framework A. Factors influencing physical health of trafficked fishermen. Conceptual Framework B. Factors

influencing healthcare responses for migrant or trafficked fishermen in Thailand. (PDF $606 \mathrm{~kb}$ )

\section{Acknowledgements}

We are grateful to post-trafficking service users and key informants who participated in the quantitative and qualitative studies respectively, without whom this research would not have been possible. We thank Artit Thaiprayoon and Varin Gambhir for transcribing and translating qualitative interviews in Thai, respectively. 


\section{Funding}

The quantitative study was funded by Anesvad Foundation and the International Organization for Migration International Development Fund, with additional support from the Economic and Social Science Research Council, UK. The qualitative study was funded by a Gordon Smith Travelling Scholarship from the London School of Hygiene and Tropical Medicine.

The funders had no role in the design and conduct of the study; collection, management, analysis, and interpretation of the data; preparation, review, or approval of the manuscript; and decision to submit the manuscript for publication.

\section{Availability of data and materials}

Due to safety concerns for and the confidentiality obligations to the posttrafficking service users who participated in the quantitative study, public sharing of data from this study is not possible because it would violate the informed consent agreement with participants. Data will be made available to qualifying researchers upon request. Data requests can be sent to the corresponding author, Nicola Pocock, at nicola.pocock@unu.edu. Participants for the qualitative study were asked for their permission to have their anonymized transcripts stored in the London School of Hygiene and Tropical Medicine's data repository (http://datacompass.lshtm.ac.uk). For participants who consented, qualitative data is not publically available to maintain confidentiality and anonymity but can be shared on reasonable request from the participant themselves and the corresponding author. Data requests can be sent to Nicola Pocock, at nicola.pocock@unu.edu, in the first instance.

\section{Authors' contributions}

LK and CZ designed the quantitative study, and NSP designed the qualitative study. NSP analyzed and interpreted the data and wrote the report. BD and SS were country coordinators for the quantitative study and collected and interpreted data. RT and WR were research assistant interpreters for the qualitative study and collected and interpreted data. NSP and KT collected and interpreted qualitative data and revised the report. LK and CZ revised the report. All authors read and approved the final manuscript.

\section{Ethics approval and consent to participate}

As noted in the Methods section, for quantitative data, written informed consent with trafficked fishermen using post-trafficking services in Thailand and Cambodia was obtained prior to interview. A strict ethics protocol based on the World Health Organization Ethical Recommendations for Interviewing Trafficked Women was followed [44]. Ethics approval was obtained from Institutional Review Boards at the Ministry of Social Development and Human Security in Thailand, the National Ethics Committee for Health Research in Cambodia and the London School of Hygiene and Tropical Medicine (LSHTM). The LSHTM IRB number is 5770 .

As noted in Methods, the port research site is not named to preserve the anonymity of participants interviewed for the qualitative component. Because of the small number of organizations and individuals working with migrant and trafficked fishermen, participants may be identifiable if the port research site is named. Written informed consent was obtained from each participant. Ethical approval was obtained from the LSHTM's Observational Ethics Committee (IRB no. 8368) and from the Institute of Population and Social Research's Institutional Review Board at Mahidol University (IRB No. 2014/1-1-22).

\section{Competing interests}

The authors declare that they have no competing interests.

\section{Publisher's Note}

Springer Nature remains neutral with regard to jurisdictional claims in published maps and institutional affiliations.

\section{Author details}

${ }^{1}$ United Nations University International Institute of Global Health, UKM Medical Centre, Jalan Yaacob Latif, Bandar Tun Razak, 56000 Cheras, Kuala Lumpur, Malaysia. ${ }^{2}$ Institute for Population and Social Research, Mahidol University, Salaya, Phutthamonthon District, Nakhon Pathom 73170, Thailand. ${ }^{3}$ Independent consultant, Bangkok, Thailand. ${ }^{4}$ International Organization for Migration, Norodom Blvd, No. 281, 4th Floor, Sangkat Tonle Basac, Khan Chamkamorn, Phnom Penh, Cambodia. ${ }^{5}$ Independent consultant, Phnom Penh, Cambodia. ${ }^{6}$ Department of Global Health \& Development, Faculty of
Public Health and Policy, London School of Hygiene and Tropical Medicine, 15-17 Tavistock Place, Kings Cross, London WC1H 9SH, UK.

Received: 14 September 2017 Accepted: 19 April 2018

Published online: 09 May 2018

\section{References}

1. Ry S. Deceived into the fishing industries: case studies of trafficked Cambodian workers [Internet]. [Bangkok, Thailand]: Chulalongkorn University; 2014. Available from: http://www.arcmthailand.com/documents/ documentcenter/SovannaRy.pdf

2. Surtees R. In African waters. The trafficking of Cambodian fishers in South Africa [Internet]. International Organization for Migration (IOM) and Nexus Institute; 2014. Available from: http://publications.iom.int/bookstore/free/ Nexus_AfricanWaters_web.pdf

3. Htusan E, Mason M. More than 2,000 enslaved fishermen rescued in 6 months. Assoc. Press - Big Story [Internet]. 2015; Available from: http:// bigstory.ap.org/article/ceecf8df237e49bf8fe59d47fa3515b0/more-2000enslaved-fishermen-rescued-6-months

4. Press A. Modern slavery: narratives of slave fishermen. 2015; Available from: http://interactives.ap.org/2015/slave-fishermen/

5. ILO. Caught at sea: forced labour and trafficking in fisheries. 2013.

6. Driscoll TR, Ansari G, Harrison JE, Frommer MS, Ruck EA. Traumatic work related fatalities in commercial fishermen in Australia. Occup. Environ. Med. [internet]. 1994;51:612-6. Available from: http://www.ncbi.nlm.nih.gov/ pubmed/7951793

7. Matheson C, Morrison S, Murphy E, Lawrie T, Ritchie L, Bond C. The health of fishermen in the catching sector of the fishing industry: a gap analysis. Occup. Med. (Chic. III). [Internet]. 2001;51:305-11. Available from: https:// www.ncbi.nlm.nih.gov/pubmed/11473136

8. Robertson P. Trafficking of Fishermen in Thailand [Internet]. Thailand: International Organization for Migration (IOM); 2011. Available from: http://unact.org/wp-content/uploads/2016/01/Trafficking-of-Fishermen-Thailand.pdf

9. EJF. Pirates and slaves: how overfishing in Thailand fuels human trafficking and the plundering of our oceans [Internet]. London, UK: Environmental Justice Foundation (EJF); 2015. Available from: http://ejfoundation.org/ report/pirates-and-slaves-how-overfishing-thailand-fuels-human-traffickingand-plundering-our-oceans

10. de Coning E. Transnational Organized Crime in the Fishing Industry. Focus on: Trafficking in Persons, Smuggling of Migrants, Illicit Drugs Trafficking. Vienna: United Nations Office on Drugs and Crime (UNODC); 2011.

11. Brennan M. Out of sight, out of mind: human trafficking and exploitation of migrant fishing boat Workers in Thailand [internet]. Solidarity Center: Bangkok, Thailand; 2009. Available from: https://www.solidaritycenter.org/ wp-content/uploads/2015/01/thailand_Out_of_Sight_Eng.pdf

12. UNIAP. Exploitation of Cambodian men at sea: facts about the trafficking of Cambodian men onto Thai fishing boats. Strateg. Inf. Response Netw. Phnom Penh, Cambodia: United Nations Inter-Agency Project on Human Trafficking (UNIAP); 2009

13. ILO, Asian Research Center for Migration Chulalongkorn University I of AS. Employment practices and working conditions in Thailand's fishing sector ILO Tripart. Action to Prot. Rights Migr. Work. within from Gt. Mekong Subreg. (GMS TRIANGLE Proj. Bangkok, Thailand: International Labour Organization (ILO); 2013.

14. Yea S. Troubled Waters: Trafficking of Filipino Men into the Long Haul Fishing Industry through Singapore. Singapore: Transient Workers Count 2 (TWC2); 2012.

15. Ottisova L, Hemmings S, Howard LM, Zimmerman C, Oram S. Prevalence and risk of violence and the mental, physical and sexual health problems associated with human trafficking: an updated systematic review. Epidemiol. Psychiatr. Sci. [internet]. 2016;1-25. Available from. http://www.ncbi.nlm.nih. gov/pubmed/27066701

16. Oram S, Abas M, Bick D, Boyle A, French R, Jakobowitz S, et al. Human trafficking and health: a survey of male and female survivors in England. Am J Public Health [Internet]. 2016:106:1073-8. Available from: http://ajph. aphapublications.org/doi/10.2105/AJPH.2016.303095

17. C. Z, M. H, C. W. Human trafficking and health: A conceptual model to inform policy, intervention and research. Soc. Sci. Med. [Internet]. 2011;32735. Available from: http://ovidsp.ovid.com/ovidweb.cgi?T=JS\&CSC= Y\&NEWS=N\&PAGE=fulltext\&D=emed10\&AN=2011384909 
18. Day K. (Re)integration of Cambodian trafficked men: Trends in trafficking and available aftercare services [Internet]. Hagar International; 2015. Available from: https://hagarinternational.org/international/our-work/ research/new-hagar-research-reintegration-of-cambodian-trafficked-men/

19. Storm T, Engberg M. The impact of immigration detention on the mental health of torture survivors is poorly documented-a systematic review. Dan Med. J. [internet]. 2013;60:A4728. Available from: http://www.ncbi.nlm.nih. gov/pubmed/24192244.

20. Oram S, Ostrovschi NV, Gorceag VI, Hotineanu MA, Gorceag L, Trigub C, et al. Physical health symptoms reported by trafficked women receiving posttrafficking support in Moldova: prevalence, severity and associated factors. BMC Womens. Health [internet], Available from. 2012;20(12) http://www. ncbi.nlm.nih.gov/pubmed/22834807

21. Turner-Moss E, Zimmerman C, Howard LM, Oram S. Labour Exploitation and Health: A Case Series of Men and Women Seeking Post-Trafficking Services. J. Immigr. Minor. Heal. [Internet]. 2013;1-8. Available from: http://link. springer.com/article/10.1007/s10903-013-9832-6

22. Meyer SR, Robinson WC, Chhim S, Bass JK. Labor migration and mental health in Cambodia: a qualitative study. J. Nerv. Ment. Dis. [internet]. 2014; 202:200-8. Available from: http://www.ncbi.nlm.nih.gov/pubmed/24566505

23. Hinton DE, Hinton AL, Eng K-T, Choung S. PTSD and key somatic complaints and cultural syndromes among rural Cambodians: the results of a needs assessment survey. Med. Anthropol. Q. [internet]. 2012;26:383-407. Available from: http://www.ncbi.n/m.nih.gov/pubmed/23259349

24. Hinton DE, Kredlow MA, Pich V, Bui E, Hofmann SG. The relationship of PTSD to key somatic complaints and cultural syndromes among Cambodian refugees attending a psychiatric clinic: the Cambodian somatic symptom and syndrome inventory (CSSI). Transcult. Psychiatry [internet]. 2013;50:34770. Available from: http://www.ncbi.n/m.nih.gov/pubmed/23630226

25. Willen SS. Migration, "illegality," and health: Mapping embodied vulnerability and debating health-related deservingness. Soc. Sci. Med. [Internet]. 2012;74: 805-11. Available from: http://www.sciencedirect.com/science/article/pii/ S0277953611007180

26. Lun M. After state counsellor's visit, overhaul of Thai migrant worker scheme expected. Myanmar Times [Internet]. 2016 Jul 1 [cited 2017 Apr 27]; Available from: http://www.mmtimes.com/index.php/national-news/21149after-state-counsellor-s-visit-overhaul-of-thai-migrant-worker-schemeexpected.html

27. Aung T, Pongpanich S, Robson M. HEALTH SEEKING BEHAVIOURS AMONG MYANMAR MIGRANT WORKERS IN RANONG PROVINCE, THAILAND. J. Heal. Res. [Internet]. 2009;23. Available from: https://www.researchgate.net/ publication/242611816_Health_seeking_behaviours_among_Myanmar_ migrant_workers_in_Ranong_province_Thailand

28. Naing T, Geater A, Pungrassami P. Migrant workers' occupation and healthcare-seeking preferences for TB-suspicious symptoms and other health problems: a survey among immigrant workers in Songkhla province, southern Thailand. BMC Int. Health Hum. Rights [Internet]. 2012;12:22. Available from: http://www.ncbi.nlm.nih.gov/pmc/articles/PMC3478184/

29. Entz A, Prachuabmoh V, van Griensven F, Soskolne V. STD history, self treatment, and healthcare behaviours among fishermen in the Gulf of Thailand and the Andaman sea. Sex. Transm. Infect. [internet]. 2001;77:43640. Available from: http://www.ncbi.n/m.nih.gov/pubmed/11714943

30. Srithamrongsawat $S$, Wisessang R, Ratjaroenkhajorn S. Financing healthcare for migrants: a case study from Thailand [Internet]. Bangkok, Thailand: WHO and IOM; 2009. Available from: http://publications.iom.int/ bookstore/free/ Financing_Healthcare_for_Migrants_Thailand.pdf.

31. Yan W. Only One Country Offers Universal Health Care To All Migrants. NPR [Internet]. 2016; Available from: http://www.npr.org/sections/goatsandsoda/ 2016/03/31/469608931/only-one-country-offers-universal-health-care-toundocumented-migrants

32. Department TGPR. Medical Check-Ups and Health Insurance for Migrant Workers [Internet]. http://thailand.prd.go.th/ewt_news.php?nid=3051\&filename=index

33. Sunpuwan $M$, Chamchan $C$, editors. Management of Health Insurance System and Health Service Provision for Migrant Workers in Thailand: Case Studies from Samut Prakan and Chiang Mai. 3rd MMC Reg. Conf. - Transnatl. Migr. Bord. Stud. Assess. Threat. Oppor. Institute for Population and Social Research (IPSR), Mahidol University; 2014.

34. Suphanchaimat $R$, Putthasri $W$, Prakongsai $P$, Tangcharoensathien V. Evolution and complexity of government policies to protect the health of undocumented/illegal migrants in Thailand - the unsolved challenges. Risk
Manag. Healthc. Policy [Internet]. 2017 [cited 2017 may 5];volume 10:49-62. Available from: http://www.ncbi.nlm.nih.gov/pubmed/28458588.

35. Pocock NS. Occupational risks, health needs and victim identification of trafficked fishermen in the Greater Mekong Subregion (GMS). [London]: London School of Hygiene and Tropical Medicine; 2017.

36. Pocock NS, Stockl H, Tadee R, Rongrongmuang W, Tharawan K, Adamson F, et al. Victims or suspects? Identifying and assisting potentially trafficked fishermen: a qualitative study with key stakeholders and first responders in Thailand. 2018.

37. Tharathep C, Thamroj N, Jaritake P. A study on appropriate health care financing and health service system for migrants - case studies from Samut Sakhon and Rayong provinces. Health Insurance System Research Office (HISRO), Health Systems Research Institute (HSRI), Raks Thai Foundation (RTF): Prev. HIV/AIDs Among Migr. Work. Thail. Proj; 2013.

38. Suphanchaimat R. "Health insurance card scheme" for cross-border migrants in Thailand: responses in policy implementation and outcome evaluation. [London, UK]: London School of Hygiene and. Tropical Medicine. 2016;

39. Press B. New health Insurance for Migrant Workers facing challenges [internet]. 2014. Available from: http://www.phamit.org/hilight-detail. php?lang=en\&id $=12$

40. Kamenketkarn P, editor. Protection of Victims of Human Trafficking, Thailand (Case Management Report) [Internet]. JICA Capacit. Build. Work. Return, Repatr. Reintegration Traffick. Pers. Cambodia, Lao PDR, Myanmar Vietnam. Chiang Mai, Thailand; 2012. Available from: http://jica-cb-workshop.weebly. com/uploads/8/0/7/2/8072630/case_management_-_thailand-2s.pdf

41. Agency IOM-UNM. Trafficked to Sea: IOM Cambodia's Repatriation Program [Internet]. Available from: https://www.youtube.com/watch?v= pzZQHdGl8kE\&feature=youtu.be

42. Kiss L, Pocock NS, Naisanguansri V, Suos S, Dickson B, Thuy D, et al. Health of men, women, and children in post-trafficking services in Cambodia, Thailand, and Vietnam: an observational cross-sectional study. Lancet. Glob. Heal. [internet]. 2015;3:e154-161. Available from. http://www.ncbi.nlm.nih. gov/pubmed/25701993

43. Zimmerman C, Hossain M, Yun K, Roche B, Morison L, Watts C. Stolen smiles: a summary report on the physical and psychological health consequences of women and adolescents trafficked in Europe. London Sch. Hyg. Trop. Med. Eur. Union's Daphne Program. Int. Organ. Migr. [Internet]. 2006;23 pp. Available from: http://same.Ishtm.ac.uk/stolen-smiles/

44. Zimmerman C, Watts C. WHO Ethical and Safety Recommendations for Interviewing Trafficked Women. Geneva, Switzerland: World Health Organization (WHO); 2003.

45. Kiss L, Yun K, Pocock N, Zimmerman C. Exploitation, violence, and suicide risk among child and adolescent survivors of human trafficking in the greater Mekong subregion. JAMA Pediatr. [internet]. 2015;169:e152278. Available from: http://www.ncbi.nlm.nih.gov/pubmed/26348864.

46. Pocock NS, Kiss L, Oram S, Zimmerman C. Labour Trafficking among Men and Boys in the Greater Mekong Subregion: Exploitation, Violence, Occupational Health Risks and Injuries. PLoS One [Internet]. 2016;11: e0168500. Available from: http://journals.plos.org/plosone/article?id=10. 1371/journal.pone.0168500

47. Miller CD, Campbell JC. Reliability and validity of the miller abuse physical symptom and injury scale (MAPSAIS). Chicago: III Midwest Nurs. Res. Soc; 1993.

48. Garcia-Moreno C, Jansen HAFM, Ellsberg M, Heise L, Watts C. WHO Multicountry Study on Women's Health and Domestic Violence against Women. Initial results prevalence, Heal. outcomes women's responses. Geneva, Switzerland: World Health Organization (WHO); 2005.

49. Garcia-Moreno C, Jansen HAFM, Ellsberg M, Heise L, Watts CH. Team WHOMS on WH and DV against WS. Prevalence of intimate partner violence: findings from the WHO multi-country study on women's health and domestic violence. Lancet (London, England) [internet]. 2006;368:12609. Available from: http://www.ncbi.nlm.nih.gov/pubmed/17027732

50. Zimmerman C, Hossain M, Yun K, Gajdadziev V, Guzun N, Tchomarova M, et al. The health of trafficked women: a survey of women entering posttrafficking services in Europe. Am. J. Public health [internet], 9. 2008;98: 55. Available from: http://www.ncbi.n/m.nih.gov/pubmed/18048781

51. Mollica RF, Wyshak G, de Marneffe D, Tu B, Yang T, Khuon F, et al. Hopkins symptom Checklist-25: Indochinese versions (HSCL-25). Man. Use Cambodian, Lao Vietnamese versions. Cambridge, Massachusetts: Harvard program in refugee trauma, Harvard School of Public Health;

52. Derogatis LR, Lipman RS, Rickels K, Uhlenhuth EH, Covi L. The Hopkins symptom checklist (HSCL): a self-report symptom inventory. Behav. Sci. 
[internet]. 1974;19:1-15. Available from: http://www.ncbi.nlm.nih.gov/ pubmed/4808738

53. Mollica R, Caspi-Yarvin Y, Lavelle J, Tor S, Yang T, Chan S, et al. Harvard Trauma Questionnaire (HTQ) Manual: Cambodian, Lao, and Vietnamese Versions. 1991

54. Textor J, Hardt J, Knüppel S. DAGitty: a graphical tool for analyzing causal diagrams. Epidemiology [internet]. 2011;22:745. Available from. http://www. ncbi.nlm.nih.gov/pubmed/21811114

55. Glymoor M. USING CAUSAL DIAGRAMS TO UNDERSTAND COMMON PROBLEMS IN SOCIAL EPIDEMIOLOGY. 2006. Available from: http://publicifsv. sund.ku.dk/nk/epiF14/Glymour_DAGs.pdf

56. Babyak M. Rescaling continuous predictors in regression models [internet]. Stat. Tips from Ed. Psychosom. Med. 2009. Available from: http://stattips. blogspot.co.uk/2009/08/rescaling-continuous-predictors-in.html

57. Braun V, Clarke V. Using thematic analysis in psychology. Qual Res Psychol [Internet]. 2006;3:77-101. Available from: http://www.tandfonline.com/doi/ abs/10.1191/1478088706qp0630a

58. PHROMPRATHANKUL B. Vitamin B1 deficiency behind deaths. The Nation [Internet]. Bangkok, Thailand; 2016; Available from: http://www. nationmultimedia.com/national/Nitamin-B1-deficiency-behind-deaths30276942.html

59. Greenpeace Southeast Asia. Turn The Tide: Human Rights Abuses and Illegal Fishing in Thailand's Overseas Fishing Industry [Internet]. Greenpeace; 2016. Available from: http://www.greenpeace.org/seasia/Press-Centre/ publications/Turn-The-Tide/

60. Doung-ngern P, Kesornsukhon S, Kanlayanaphotporn J, Wanadurongwan S, Songchitsomboon S. Beriberi outbreak among commercial fishermen, Thailand 2005. Southeast Asian J. Trop. Med. Public health [internet]. 2007; 38:130-5. Available from: http://www.ncbi.nlm.nih.gov/pubmed/17539258

61. Today P. สธ.เตือนกลุ่มลูกเรือประมงเสียงขาดวิตามินปี1. http://www.posttoday.com [Internet]. 2016; Available from: http://www.posttoday.com/social/ health/471067

62. Verbeek J, Ivanov I. Essential Occupational Safety and Health Interventions for Low- and Middle-income Countries: An Overview of the Evidence. Saf. Health Work [Internet]. 2013 [cited 2017 May 8];4:77-83. Available from: http://www.sciencedirect.com/science/article/pii/S209379111300005X

63. Suphanchaimat R, Kantamaturapoj K, Putthasri W, Prakongsai P. Challenges in the provision of healthcare services for migrants: a systematic review through providers' lens. BMC health Serv. Res. [internet], Available from. 2015;15(390) http://www.ncbi.nlm.nih.gov/pubmed/26380969

64. Galdas PM, Cheater F, Marshall P. Men and health help-seeking behaviour: literature review. J. Adv. Nurs. [Internet]. Blackwell Science Ltd; 2005 [cited 2017 May 30];49:616-23. Available from: http://onlinelibrary.wiley.com/doi/ 10.1111/j.1365-2648.2004.03331.x/abstract

65. Sirilak S, Okanurak K, Wattanagoon Y, Chatchaiyalerk S, Tornee S, Siri S. Community participation of cross-border migrants for primary health care in Thailand. Health policy plan. [internet]. 2013;28:658-64. Available from: http://www.ncbi.nlm.nih.gov/pubmed/23132916

66. Press B. The PHAMIT story: the experience of an NGO-led grant by the Global Fund to fight AIDS. Raks Thai Foundation: Tuberculosis and Malaria to increase HIV prevention among migrant workers in Thailand; 2011.

67. ILO. Happy New Year from TRIANGLE! Newsletter and updates. 2017.

68. Jitthai N. Healthy Migrants, Healthy Thailand: A Migrant Health Program Model. Bangkok, Thailand: International Organization for Migration (IOM), Ministry of Public Health (MOPH), Thailand; 2009

69. Paradise RK, Choi YS, Cundiff L, Khaliif M, Nevill L, Marlin RP, et al. The Language Services Documentation Tool: Documenting How Patient Language Needs Were Met During Clinical Encounters. Jt. Comm. J. Qual. patient Saf. [Internet]. 2014 [cited 2017 may 8];40:522-3. Available from: http://www.ncbi.nlm.nih.gov/pubmed/26111370.

70. Blanchfield BB, Gazelle GS, Khaliif M, Arocha IS, Hacker K. A framework to identify the costs of providing language interpretation services. J. Health Care Poor Underserved [Internet]. 2011 [cited 2017 May 8];22:523-31. Available from: http://muse.jhu.edu/content/crossref/journals/journal_of_ health_care_for_the_poor_and_underserved/v022/22.2.blanchfield.html

71. Steel Z, Chey T, Silove D, Marnane C, Bryant RA, van Ommeren M. Association of torture and other potentially traumatic events with mental health outcomes among populations exposed to mass conflict and displacement: a systematic review and meta-analysis. JAMA J. Am. Med. Assoc. [internet]. 2009;302:537-49. Available from: http://www.ncbinlm.nih. gov/pubmed/19654388
72. Surtees R. Trafficked men as unwilling victims. St Antony's Int Rev. 2008;4:16-36.

73. Williamson E, Dutch NM, Clawson HJ. Evidence-Based Mental Health Treatment for Victims of Human Trafficking. U.S. Department of Health and Human Services, Office of the Assistant Secretary for Planning and Evaluation; 2010.

74. Surtees R. Trafficked at sea: the exploitation of Ukrainian seafarers. NEXUS Institue \& International Organization for Migration; 2013.

75. Zweynert A. After slavery, trafficked fishermen face lonely road to recovery. Thomson Reuters Found. [Internet]. 2015; Available from: http://www. reuters.com/article/us-asia-migrants-trauma-idUSKCNOPMOBT20150712

76. Cambodia IOM. Assessment of the experience and needs of repatriated male victims of trafficking focus group discussions (FGD) facilitated by IOM in Banteay Meanchey. Kampong Cham, Oudor Meanchey. Phnom Penh, Cambodia: Phnom Penh; 2013.

77. Royal Thai Embassy WDC. SUMMARY OF THAILAND'S TRAFFICKING IN PERSONS REPORT 2015 (JANUARY - MARCH 2016) [Internet]. 2016. Available from: http://www.thaianti-humantraffickingaction.org/Home/?p=1883

78. Mollica RF, Wyshak $G$, de Marneffe $D$, Khuon F, Lavelle J. Indochinese versions of the Hopkins symptom Checklist-25: a screening instrument for the psychiatric care of refugees. Am. J. Psychiatry [internet], Available from. 1987(144):497-500. http://www.ncbi.nlm.nih.gov/pubmed/3565621

79. Mollica RF, Caspi-Yavin Y, Bollini P, Truong T, Tor S, Lavelle J. The Harvard trauma questionnaire. Validating a cross-cultural instrument for measuring torture, trauma, and posttraumatic stress disorder in Indochinese refugees. J. Nerv. Ment. Dis. [internet]. 1992;180:111-6. Available from: http://www.ncbi. nlm.nih.gov/pubmed/1737972

80. Cahill SP, Pontoski K. Post-Traumatic Stress Disorder and Acute Stress Disorder I. Psychiatry (Edgmont) [Internet]. 2005;2:14-25. Available from: http://www.ncbi.nlm.nih.gov/pmc/articles/PMC3004735/

81. Greenland S, Pearl J, Robins JM. Causal diagrams for epidemiologic research. Epidemiology [internet]. 1999;10:37-48. Available from: http://www.ncbi.nlm. nih.gov/pubmed/9888278

82. UNIAP. (Re) Integration: perspectives of victim service agencies on successes and challenges in trafficking victim (re) integration in the Greater Mekong SubRegion. United Nations Inter-Agency Project on Human Trafficking; 2012.

83. Surtees R. After trafficking: experiences and challenges in the (re)integration of trafficked persons in the greater Mekong sub-region. UNIAP/NEXUS Institute: Bangkok, Thailand; 2013.

\section{Ready to submit your research? Choose BMC and benefit from:}

- fast, convenient online submission

- thorough peer review by experienced researchers in your field

- rapid publication on acceptance

- support for research data, including large and complex data types

- gold Open Access which fosters wider collaboration and increased citations

- maximum visibility for your research: over $100 \mathrm{M}$ website views per year

At BMC, research is always in progress.

Learn more biomedcentral.com/submissions 